CATALAN REVIEW

Catalan Review

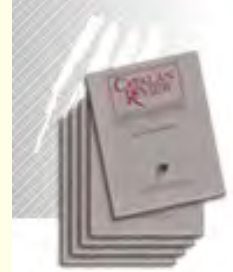

You are accessing the Digital Archive of the Catalan Review Journal.

By accessing and/or using this Digital Archive, you accept and agree to abide by the Terms and Conditions of Use available at http://www.nacs-

catalanstudies.org/catalan review.html

Catalan Review is the premier international scholarly journal devoted to all aspects of Catalan culture. By Catalan culture is understood all manifestations of intellectual and artistic life produced in the Catalan language or in the geographical areas where Catalan is spoken. Catalan Review has been in publication since 1986.
NORTH

AMERICAN

CATALAN

SOCIETY
Esteu accedint a l'Arxiu Digital del Catalan Review

A l' accedir i / o utilitzar aquest Arxiu Digital, vostè accepta i es compromet a complir els termes i condicions d'ús disponibles a http://www.nacs-

catalanstudies.org/catalan review.html

Catalan Review és la primera revista internacional dedicada a tots els aspectes de la cultura catalana. Per la cultura catalana s'entén totes les manifestacions de la vida intel lectual i artística produïda en llengua catalana o en les zones geogràfiques on es parla català. Catalan Review es publica des de 1986.

\title{
The Ordinacions de la Vall de Ribes (1347): An Edition and Linguistic Study Philip Rasico
}

Catalan Review, Vol. XIII, number 1-2, (1999) p. 203-212 


\section{THE ORDINACIONS DE LA VALL DE RIBES (1347): AN EDITION AND LINGUISTIC STUDY}

\section{PHILIP RASICO}

\section{INTRODUCTION}

Since the earliest records in which the Vall de Ribes appears, where it is mentioned as the Vallis Petrariensis or Vall Pedrera (1oth-12th centuries) alongside the Valle Ripparum (922) or Vallis de Ripis (1087), this region has been recognized as a unique and well-defined geopolitical entity within the northern Catalan comarca of the Ripollès. Situated in the extreme northwestern sector of the latter, in the upper valley of the Freser River, the Vall de Ribes is virtually surrounded by mountain ranges. It is bordered on the north by the Alta Cerdanya and the Conflent, on the south by the Baix Ripollès, on the east by the Vall de Camprodon, and on the west by the Baixa Cerdanya and the Alt Berguedà. In contrast to the rest of the Ripollès, which today is included in the diocese of Vic and formerly was divided between the latter and the diocese of Girona, the Vall de Ribes has always belonged ecclesiastically to the diocese of Urgell and administratively it formed part of the Comtat de Cerdanya until approximately the early fourteenth century (Coromines et al, 6.382s; Pladevall 380, 385). These religious and political ties have contributed to the distinctive linguistic character of the Vall de Ribes where during the Middle Ages there was spoken a variety of the Catalan language that closely resembled that of the comarques which formed the old Comtat de Rossello: Rossello, Vallespir, Conflent, Capcir, and Cerdanya (Coromines 1974: 280-281).

The present study consists of a philological transcription and linguistic analysis of the Ordinacions de la Vall de Ribes (hereafter abbreviated OVRibes), a mid-fourteenth century text concerning local statutes or laws which presumably was written in situ at the behest of the local veguer or chief magistrate Francesc de Ribes. As such it is intended as both a contribution to the study of the Catalan of this region and as a complement to an earlier study by this writer on the language of the Vall de Ribes in the late thirteenth century. ${ }^{1}$

The document in question consists of two pieces of parchment, joined together by parchment strips and measuring $666 \mathrm{~mm}$. in length by $293 \mathrm{~mm}$, in width, the second piece of which begins with line 39 .

ISee Rasico, Estudis $i$ docs., 160-201, for an edition and linguistic commentary of the Capbreu de la Vall de Ribes (ca. $128 ;-84$ ). An incomplete transcription of the Capbreu de la tall de Ribes was published in 1873 by Alart, $48-61$. 
Although both sections of the document appear to be from the same period and to have been recorded by the same scribe, only the second parchment bears a date (1347). A question therefore remains as to whether the two sewn pieces of parchment may in fact represent copied portions of two distinct documents, perhaps of different dates, concerning the statutes of the Vall de Ribes. The manuscript, which has many holes and is badly stained by moisture in some parts and faded in others, is incomplete and may represent an early draft of the OVRibes. It was acquired by the Biblioteca de Catalunya in 1978 from Joan Gili, the noted Catalan scholar, publisher and bookseller of Oxford, England, who in turn had received it from Josep Porter of Barcelona. The document is currently located in the Archive Section of the Biblioteca de Catalunya where it was catalogued in 1996 as Pergami $15.343 .{ }^{2}$ To the best of my knowledge it has remained unedited until the present time,

While the manuscript of the OVRibes presents a number of interesting linguistic features, especially insofar as its phonology is concerned and also to some extent its lexicon, one notes in general the lack of morphosyntactic structures of interest; and the same may be said for toponyms and anthroponyms. This lack may be explained in part by the fact that what remains of the text is merely a fragment of the original document. However, even insofar as the phonological features of the language of the manuscript are concerned, the standardizing linguistic consequences of the Cancilleria Reial appear evident when compared to the features of the Capbreu de la Vall de Ribes which was written some sixty-three years earlier. Even in the case of the Capbren, though, the dialect-levelling influence or "marea invasora de la koinè catalana" may be noted, as Coromines has observed (Lleures 281).

The criteria used for the establishment of the present edition of the OVRibes are, with some slight modification, those proposed and described by Russell-Gebbett.

\section{EDITION OF THE “ORDINACIONS DE LA VALL DE RIBES"}

[RECTO] Item (...) del senyor Rey q[ue en] la val de Ribes no.s gos vendre carn de vacha ne de $/ 2$ bestia [s]cortxada de qualque nat[ur]a sie ne bestia qui sia morta per lops ho per bous ho per colp ho per radura

2 The catalogue information or fitxa of the Biblioteca de Catalunya concerning this manuscript is as follows: Registre: 15343. Signatura: Caixa 55. 1347 (Ribes de Freser). Ordinacions de Francesc de Ribes, veguer de la Vall de Ribes. Suport: Pergamí. Llengua: Catala. Observacions: Format per dos peces de pergami unides amb tiretes de pergami. Procedència: Compra Gili d'Oxford, procedent de Porter: Mides: 666 × 293 . ${ }_{3} C f$. Note $r$ above. 
ho per qualque mal sia morta $\beta$ (...) no.s gos vendra tro que sie jutyade per sobreposats del loch, ho si sobreposats no y a que sia jutyade per los cossols del / $/ 4$ loch sots pena de.V. sous. E.ls jutyadors ayan de quada bestia grossa $\mathrm{I}^{\mathrm{a}}$. liura de carn et de vadel miya $/^{5}(\ldots)$ de (...) bestias .I. diner.

$/^{6}$ Item que (...) no gos vendre en la dita val de Ribes carn de cabra oltra .V. diners la liura ne oveyla oltra .IIII. diners $/^{7}$ (...) sots pena de .V. sous.

$/^{\mathrm{S}}$ Item que negu qui scortxa molto per vendra de Sancta Marie d'agost anant tro que per los dits sobreposats sie laxat ho per los dits $/{ }^{9}$ cossols ab voluntat de la cort si aquel ssera vist pecador e d'aqui avant no.l deya negu voler per sa propria actoritat puyar $/ 10$ tro per los dits sobreposats sie ordonat sots la dita pena de.V. sous.

/11 Item que negun cossol ne sobreposat aytals coses no deya fer sens licencia de la cort sots pena de.XX. solidos, puyar ne baxar $/ 12$ la carnalatge cant ha jutyar les carns naufrayades no les cayla damanar la cort mas que layalment s'aye en aqueles coses $/^{13}$ per lo sagrament que auran feyt a la cort.

${ }^{14}$ Item que negu strany ne privat dins th val de Ribes no gos vendra ne compra<r> blat ne vi ne oli sino a mesures dretes de la $/^{15} \mathrm{val}$ sots pena de .XX. sous entre lo comprador e.l venedor pecadors. $/ 16$ Item que en lo canto del oli deya aver. VI. oletes e nagu qui ab mayor ho ab manor oleta vanes que li costaria.V. sous.

$/{ }^{17}$ Item que en tota la val de Ribes negu ne naguna strayn ne privat no gos vendra ne comprar si no a pes dret de la val de qualque /18 mercaderia se sie ne liura drap sino a cana dreta de la val sots pena de (...) [so]us entre lo comprador e.] venedor./ ${ }^{19}$ Empero si.l comprador ho venedor eren stranys e no sabien les ordonacions (...) ta la pena.

120 Item que negun taverner ni tavernera en tota la val de Ribes qui vena vi en taverna no gos vendra vi oltra d'un canadel ensus $/ 21$ tro $\langle q u e>$ sie jutyat per los sobreposats del loch ho per los cossols si sobreposats no y a sots pena de.V. sous. E que.ls dits $/ 22$ sobreposats sagelen los vaxels ho dorchs hon lo dit vi metran. ${ }^{23} \mathrm{E}$ si.l taverner ho tavernera de.qui avant fara frau en lo dit vi que li costaria.XX. sous. E si.l dit frau faya $/ 24$ ab consentiment del sobreposat costaria al sobreposat.L. sous.

125 Item naguna flaquera no gos pastar sino a.quel pes que per la cort ho per sobreposat li sera donat. $\mathrm{E}$ aquel no deya crexer 26 ne mirvar sens licencia dels sobreposats sots pena de.X. sous. 
27 Item que tota flaquera que past pa per vendre si forment li costa VIII solidos ni IX. la migera que deya aver en quescuna fogacza /28 de .II. diners. XIX. unces de pa barutelat, be cuit e be asaonat sots pena del pa a perdra e sots pena de.V. sous. $129 \mathrm{Si}$ per aventura li costa lo froment, X, ho .XI. ho. XII. sous deya aver en la dita fogacza.XVII. unczes sots la forma ${ }^{30}$ (...) [di?]ta e d'aqui amunt segons mes e menys, segons que per los dits sobreposats sera aordonat ab volentat de la $/ 31$ (...) $[$ cort?],

$\beta 2$ (...) poder als sobreposats que ab licencia de la cort pusquen donar mesuras de vi e regonexer aqueles e donar pes de pa $\beta 3$ (..) pa a perdra lo pa mirve e aquel a portar a la cort, e pusquen lavar penyores de les penes, e que.ls dits sobreposats ayan $\beta^{34}(.$.$) lo tercz (...) la meytat del pa.$

${ }^{35}$ Item que si alcun so[breposat ne] cossol usan de.questes coses celava nega[n] qui aytals fraus agues comeses pagara lo sobreposat ${ }^{\beta 6}$ (...).

${ }^{37}$ Item negu qui tengues falsa messura ho falsa cana ho fals pes pagara .LX. sous.

${ }^{38}$ Item negu qui tengues falses mesures de vi ho d'oli pagara.V. sous.

139 Apres, a .XIII. dies de juny l'an de nostre senyor M.CCC.XLVII, $1^{40}$ l'onrat en Francesch de Ribes vaguer de la val de Ribes feu les $/^{+1}$ ordonacions dejos scrites.

$1^{42} \mathrm{E}(\ldots)$ en la val de Ribes fossen trobades moltes de mesures axi de blat quom de vi e d'oli e d'altres coses que.s venen a mesura les unes masa $/^{43}$ grans e les altres masa poques, e les gens allegasen necligencia dien que lonch temps avie que no s'eren combatudes. Enm per amor d'aczo l'onrat $/^{44}$ Francesch de Ribes vaguer de la val de Ribes feu les ordonacions qui $\square$ s seguexen.

${ }^{45}$ Primerament aordona e mana esser tengut e servat en la dita val axi per los strayns com per aquels de la dita val que nagu no vena $/ 46$ ne compra neguna mercaderie qui.s vena a pes si no a pes dret de la dita val sots pena de.XX. sous a la cort del senyor $/^{47}$ Rey goanyats.

148 Item que negu ne neguna no compra ne vena neguna mercaderie en la dita val qui,s vena a mesura si no a dreta mesura de la $/^{49}$ dita val si es de vi ho d'oli ho de blat ho d'altres coses que.s liuren a mesura, ne liura drap si no a dreta cana de la dita val sots ${ }^{50}$ pena de.XX. sous a la cort del senyor Rey goanyats. 
${ }^{51}$ Item que negun hom no vena carn de bestia enderocada ho orade ho que agues altra malaltia ho que fos morte per lop ho per aviam $/ 52$ tro que fos juty[a]de per los sobreposats ho per los cosols si sobreposats no y a sots pena de.XX. sous.

$1^{53}$ Item que cascu deya dir als dits sobreposats ho cossols lo mal per que la bestia s'a morta, e si no u faye e.n deya falsie pagara $/ 54$ a la cort del senyor Rey . LX. sous.

155 Item que negun taverner no gos vendra vi tro que sie jutyat per los dits sobreposats ho per los cosols si sobreposats no y a $/ 56$ sots pena de .XX. sous. $/^{57}$ Empero si algun taverner prenia mig canadel ho d'equi aval $\mathrm{d} e \mathrm{vi},[\mathrm{e}]$ que no.n preses pus plegat, aquel pogues vendre sens jutyar.

158 Item que negun flaquer no gos pastar pa si no a pes que el sera dat per los sobreposats ho per los cosols si sobraposats no y ha sots $/^{59}$ pena de .XX. sous e.l pa a perdre.

$1^{60} \mathrm{E}$ ayan los sobreposats per jutyar de les dites coses de cascuna bestia bovina que jutyaran. I. son e de les altres besties $/ 61$.I. diner.

162 Item de vi a jutyar per cascuna vegade que.l jutyaran. I. diner de vi e que y meten .I. diner d'ayga.

${ }^{63}$ Item ayen per los pes a donar de les flaqueres de cascun.I. diner per quascuna vagada que pes los donen. $/^{64} \mathrm{E}$ si negu ho neguna cahia en los dits bans auria lo tercz aquel qui u acusari[a]. $165 \mathrm{E}$ si per aventura los dits sobreposats sabien algun qui fos cahut en algun ban de les coses desus dites e no.l acusava ho $/ 66$ que.l celas per qualque raho pagarie .LX. sous. $/ 67$ E cascun sobreposat aye licencia e poder de destrenyer e de penyorar los dits bans. $/ 68 \mathrm{E}$ si [negu] o neguna tenia falsa mesura fos pe[s] de blat ho de vi ho d'oli ho fals pes de quesque.s fos ho falsa cana $/ 69$ sots pena de cosiment de la cort axi com de dret fos.

[VERSO] Hordinasions fetes per la val de Ribes $/ 2$ sobre lo politich del publich.

\section{LINGUISTIC COMMENTARY}

As previously has been observed, there is nothing particularly remarkable insofar as the morphological and syntactic features of the text are concerned. Therefore, only those phonological traits and 
lexical items considered to be of sufficient interest will be considered in the discussion which follows. 4

\section{Vowels}

While there are no exeptional examples discovered involving tonic vowels, it is perhaps significant to note that the distinction between the reflexes of the groups ACT and ECT are continued in their respective results eyt and et: feyt $\left(\mathrm{I}_{3}\right)<$ FACTU, in contrast to dret $(17,46,69)<$ DIRECTU, dreta $(18,48-49)<$ DIRECTA, dretes $(14)<$ DIRECTAS.

Insofar as unstressed vowels are concerned, both pretonic and posttonic, numerous examples are found of the confusion of the descendants of Vulgar Latin atonic /e/ and /a/, which evidently have merged as the mid-central or neutral vowel [ə].

In pretonic position: equi $<$ ECCU-HIC (cf. d'aqui 9 ), vadel $(4)<$ VITELLU, layalment (12) < LEGALMENTE, nagu $(16,45)<$ NECUNU (cf. negu 14, 17), naguna $(17,25)<$ NEC-UNA (cf. neguna 46), sagelen (22) < SIGILLU (cf. Cat. segell, segellar), flaquer (58) and flaquera $(25,27)<*$ FLECARIU - A, lavar $(33)<\operatorname{LEVARE,~vaguer~}(40$, 43) < VICARIU, sobraposats (58) < SUPER-PAUSATOS, vagada (63) $<$ VICATA (cf. vegade 62), vanes (16) < VINDISSET, manor $(16)<$ MINORE.

In posttonic position: vendra $(3,8,14)<$ VINDERE (cf. vendre 1 ), sie $(2,8,10)<$ "SIAT (cf. sia 2), jutyade $(3,52)<$ IUDICATA, aye (12, $67)<$ HABEAT, ayan $(4,33)<\mathrm{HABEANT}$, vegade $(62)<\mathrm{VICATA}$ (cf. vagada 63), bestias (5) < BESTIAS, lliura (18) < LIBERET, mesuras (32) < MENSURAS (cf. mesures 38, 42), perdra (33) < PERDERE, avie (43) < HABEBAT, mercaderie $(46,48)<$ MERCATU (> Cat. mercat, mercader, mercaderia, etc.), arade (SI) < *AURATA, morte (5I) < MORTA, faye (53) < FACEBAT, falsie (53) < FALSIA.

An isolated example of atonic $/ o />[u]$ appears in $u(53,64)<$ HOC (> Cat. bo), which, given its context before a following /i/ (e si no $u$ faye; aquel qui $u$ acusari[a]) may be due to dissimilation.

Among other vocalic phenomena there may be noted the loss of the glide $u([\mathrm{w}])$ in ayga $(62)(<$ aigua $)<{ }^{* A C Q U A, ~ a ~ l o s s ~ t h a t ~ i s ~ w e l l ~}$ documented in both medieval and modern Catalan dialects.

4 In general only the first three occurrences of a particular phonological phenomenon will be cited. 


\section{Consonants}

Insofar as the consonantal phonemes are concerned, the manuscript of the OVRibes appears to preserve the contrast between the voiceless alyeolar fricative $5-/$-ss- $(/ \mathrm{s} /<\mathrm{S}-,-\mathrm{SS}-)$ and the voiceless dental affricate f / ts/ (< CE-, CY, Cons.TY, etc.): licencia (II, 26, 32) < LICENTIA, fogacza $(27,29)<$ FOCACIA, unces $(28)$, unczes (29) < UNTIA(S), tercz $(34,64)<$ TERTIU, celava $(35)<$ CELABAT, celas $(66)<$ CELAVISSET, aczo (43) < ECCE-HOC. ${ }^{5}$

Nevertheless, no such opposition is found between the orthographic representation of OCat. /s/ and $/ \mathrm{z} /(<-\mathrm{S}-)$, although these two phonemes have always been distinguished in the speech of the Vall de Ribes: grossa (4) < GROSSA, esser (45) < *ESSERE, in contrast to masa $(42-43)<$ MASSA, messura (37) < ME(N)SURA (cf. mesura $42,48-49$; mesures $14,38,42$; mesuras 32 ).

A consistent distinction is seen in the Old Catalan reflexes of the groups-LY-, -C'L-, -G'L- (> OCat, /y /) on the one hand, and that of - $\mathrm{LL}$ - and $\mathrm{L}-(>/ K /)$ on the other, a difference which Coromines notes is maintained in the Vall de Ribes where [béy] (< vell), [béyə] (< vella) $<$ VEC'LU -A are still heard (Coromines, EntreDL I.38). Thus, in the OVRibes one finds oveyla $(6)<$ OVIC'LA, cayla (12) < CALEAT; oleta (16) and oletes (16) < OLLITTA, val (1, 6, I4) < VALLE, vadel (4) $<$ VITELLU, canadel (20) < CANNATELLU, vaxels $(22)<$ VASCELLOS, aquel $(9,25,33)<$ ECCU-ILLU (cf. aqueles 12,32 ), lop (5I) and lops (2) < LUPU -OS, loch $(3-4,2$ I) $<$ LOCU, liura $(6)<$ LIBRA, lavar (33) < LEVARE, lonch (43) < LONGU.

A contrast is revealed as well between the evolution of the descendants of NY, $-\mathrm{GN}->n y(/ \mathrm{n} /)$ and $-\mathrm{NN}->n(/ \mathrm{n} /)$, the latter a result typical of Roussillon and the Pyrenean region in general, as well as much of the Western Catalan area (Coromines DE Cat I.337, 2.495): strany $(14,17)$ and stranys $(19,45)<$ EXTRANEU -OS, juny $(39)<$ JUNIU, senyor $(1,39,46)<$ SENIORE, destrenyer $(67)<$ DISTRINGERE, penyorar (67) < PIGNORARE; an (39) < ANNU, cana (I8, 37, $68)<$ CANNA, canadel (20) < CANNATELLU.

The ancient voiced dental fricative /ð/, which was a very weak and

5. Coromines (EntreDL I.27) observes that the majority of 13 th and 14 th century documents from the Vall de Ribes maintain the etymological distinction between/s/and 11. However he attributes the confusion (as/s/) discovered in the Capbreu de la Vall de Ribes to the intervention of a scribe "rossellones o conflenti de confiança del rei Jaume [de Mallorca], mentre que després de la pau de 1298 tornarien a ser més els escribes local, els quals distingien."

6 In the case of $\operatorname{cossol}(s)(3,11,35)$ and $\operatorname{cosol} 5(52,55,58)(<$ semilearned consol $(5))<$ CONSUL(ES), the devoicing of the reflex of -NS - which normally gives / $z$ / in Catalan, is typical of dialects from the northern regions including rossellones, and it is also found in Occitan dialects (Coromines, DECat $2.885-887$ ). 
ephemeral phoneme resulting from the deaffrication of older $/ \mathrm{dz} /(<-$ TY-, $-C^{e, i}$ ) and which in most instances disappeared in pretonic position while vocalizing to $-u([w])$ in syllable-final and word-final position, has been lost in most forms: rabo (6o) < RATIONE, asaonat (28) (< assaonar < saó < [saðón] < [sadzón]) < SATIONE, faya $(23)(=$ faia), faye (53) < FACEBAT, deya (53) < DICEBAT, dien (43) < DICENDO. The fricative result of $-\mathrm{D}$ - which merged with that of anc. /dz/ as /\%/ also has been effaced in cabia (64) < CADEBAT. Examples of the vocalization of the same early denat fricative are feu $(40,44)<$ FECIT, frau (23) and fraus $(35)<$ FRAUDE(S). 7 The case of radura (2) < RASURA evidently constitutes a case of dissimilation, occasioned by the initial vibrant $(/ \mathrm{rr}-/)$, in which etymological / $\mathrm{z} /(<-$ S-) has become a dental fricative similar to anc. / / / (cf. MCat. rasura). 8

The text reveals without exception the loss of word-final $/ \mathrm{n} /(<-$ N'): molto (8) < MOLTON(E) (cf. raho 60), vi $(14,20,22)<\mathrm{VIN}(\mathrm{U})$, pa $(27-28,32)<\operatorname{PAN}(\mathrm{E})$, canto $(16)<\mathrm{CANTON}(\mathrm{E})$, negu $(9,14,17)<$ NEC-UN(U) (cf. nagu I6, 45), be (28) < BEN(E)?

An orthographic distinction is consistently made between the voiced palatal fricative $/ z /$, which the manuscript of the OVRibes renders normally as $y$ but also as $g$, and the voiced palatal affricate $/ \mathrm{dZ} /$ which is respresented as ty and tg: miya (4) < MEDIA, deya $(9,11,16)<$ DEBEAT, puyar $(9, \mathrm{II})<$ PODIARE, naufrayades (12) < NAUFRAGATAS, ${ }^{10}$ aye $(12,67)<$ HABEAT, ayen $(33,63)<$ HABEANT, mayor $(16)<$ MAIORE, migera (27) < MEDIARIA; jutyade (3, 52), jutyadors (4), jutyar (12, 57, 60), jutyat $(21,55)$, jutyaran $(60,62)$ which are all derived from Latin IUDICE $(>$ Cat. jutge), and carnalatge (12) < CARNALATICU.

Finally, mention should be made of the consistent use of the digraph $-c h$ in word final (and radical-final) position to represent the voiceless velar stop [k]. Thus loch $(3-4,2 \mathrm{I})<\operatorname{LOCU}$, lonch $(43)<$ LONGU, Francesch $(40,44)<$ FRANCISCUS, dorchs $(22)<$ ORCA.

\section{Lexicon}

There are three lexical forms which merit particular attention here:

Naufrayades (12), by its context, appears to be from the verb nafrar 'to wound, to injure' (cf. past part. nafrat-da), and suggests the meaning 'damaged, harmed': les carns naufrayades 'damaged meat',

7 On the evolution of anc. $10 /$, see especially Coromines, Lleures C, 209-216; Gulsoy, Estudis gram. bist., 123-168; Rasico, Estudis fon. prelit. , 135-173.

8 Sec Coromines, LleuresC, 253-259.

9 The loss of $-n$ has been studied by Rasico, Estudis fon prelit., 218-231, Estudis 1 docs., 36-51, and by Gulsoy, "Tractament de la $\rightarrow x$, , $33-81$.

10 This form will be commented upon below, since its morphophonological structure and etymology present a number of problems. 
perhaps referring to that of poor quality or irregular appearance. Coromines (DECat 5.866-869) derives nafrar as well as nafragar from *NA(VI)FRAGARE, which in turn was derived from NAVIFRAGUS. This explanation, however, does not account for naufrayades [nawfradżádes] in the OVRibes. A reading naufragades 'shipwrecked' (< naufragar < NAUFRAGARE) is possible assuming a scribal error ( $y$ for $g$ ). However, according to Coromines (DECat 5.887-888) Cat. naufragi 'el fet de naufragar' (< NAUFRAGIUM) and its variant naufraig have the figurative meaning 'pèrdua gran' and that today in the Balearic dialects the use of naufraig 'desgràcia, danys' is common. The same scholar also notes the occurrence of the form naufratge in a document from 1313 and cites the use of naufraig 'dany, perjudici' in another Catalan document from the $14^{\text {th }}$ or $15^{\text {th }}$ century with reference to the Balearic Islands. It would appear, therefore, that naufrayades found in the OVRibes represents the perfect participial form of naufrajar ([nawfrazá(r)]) 'to damage, to harm', a heretofore undocumented hapax derived from semilearned Cat. naufraig."

Dorchs (22), the plural of dorc(b) together with its variant dorca (pl. dorques) 'espècie de gerra per posar-hi oli, aigua, vi, etc.', both of which are also found in Occitan, appear to derive from Lat. ORCA 'jar, jug, pitcher, barrel' with influence from synonymous doll (<DOLIUM) and Oc. dorn, dorna. According to Coromines, Cat. dorc and dorca "Són mots peculiars del domini rossellonès, incloent-hi Cerdanya, Ripollès i algunes localitats berguedanes i gironeses. Dorc sobretot és molt freqüent en la documentació antiga rossellonesa" (DECat 3.187-188),

Barutelat (28) 'of sifted flour': XIX. unces de pa barutelat, the etymology of which is unclear. According to Corominas and Pascual, "[Gallego-asturiano] Bortelar, [occitano] barutelar y [occitano y gallego] barutar son las formas etimológicas de este grupo léxico tomado del oc. ant. barutel, barutelar, alguna vez balutar, cat. ant. barutell, fr, ant. beluter, buleter. La etimología permanece oscura (aunque desde luego es voz de origen transpirenaica en cast. y gallego)" (DCECH 1.532). However, neither Coromines' DECat nor Corominas and Pascual's DCECH provides any historical documentation of barutell(ar) in Catalan, and, therefore, the mention of barutelat in the OVRibes is of considerable interest. ${ }^{12}$

\section{PHILIP D. RASICO VANDERBILT UNIVERSITY}

u DuCange (5.578) cites the use of naufragiare (<NAUFRAGIUM) in a French document from the year 697 .

12 Alcover and Moll (DCVB 2.339), however, cite the form barutell in a manuscript attributed to Saint Pere Pasqual, as reported by Marià Aguiló (Dicc. Agailó t.203), as well as baratellat in the fourteenth-century Catalan version of the Tresor de Pobres (column 41) compiled by Pere Hispano (Pope John XXI). 


\section{WORKS CITED}

Aguilo, Marià, Diccionari Aguiló. Materials Lexicogràfics Revisats $i$ Publicats sota la Cura de Pompen Fabra i Manuel de Montoliu. 8 vols. Barcelona: Institut d'Estudis Catalans, 1915-34.

AlART, J. B. "Documents sur la langue catalane des anciens comtés de Roussillon et de Cerdagne". Revue des Langues Romanes 4 (1873): 48-6I.

Alcover, Antoni M. and Francesc de B. Moll, Diccionari CatalàValenciä-Balear. to vols. Palma de Mallorca: Editorial Moll, 192668.

Corominas, Joan and José Antonio Pascual. Diccionario Crítico Etimológico Castellano e Hispánico, 6 vols. Madrid: Editorial Gredos, 1980-91.

COROMINES, Joan. Lleures $i$ converses d'un filòleg. $2^{\text {nd }}$ ed. Barcelona: Club Editor, 1974 .

-... Entre dos llenguatges. 3 vols. Barcelona: Curial Edicions Catalanes, 1976 6-77.

Coromines, Joan and J. Gulsoy, Diccionari etimolòic i complementari de la llengua catalana. 9 vols. Barcelona: Curial Edicions Catalanes and La Caixa, 1980-91.

Coromines, Joan et al. Onomasticon Cataloniae. 8 vols. Barcelona: Curial Edicions Catalanes and La Caixa, 1989-97.

DU CANGE (Charles du Fresne). Glossarium Mediae et Infimae Latinitatis. 10 vols. Niort: L. Favre, 1883-87.

Gulsoy, Joseph. Estudis de gramática històrica. Valencia and Barcelona: Institut Interuniversitari de Filologia Valenciana and Publicacions de l'Abadia de Montserrat, 1993.

-... "El tractament de la $-n<-\mathrm{N}$ ' en català", Caplletra 20 (1996): 33-8I.

Pladevall, Antoni. Gran geografia comarcal de Catalunya, i: OsonaEl Ripollès. Barcelona: Fundació Enciclopèdia Catalana, 1982.

RAsico, Philip D. Estudis sobre la fonologia del català preliterari. Barcelona: Publicacions de l'Abadia de Montserrat, 1982.

---. Estudis $i$ documents de lingüistica bistòrica catalana. Barcelona: Curial Edicions Catalanes, 1993.

Russell-GebBeTT, Paul. Mediaeval Catalan Linguistic Texts. Oxford: Dolphin, 1965. 